\title{
Videothoracoscopic Right Pneumonectomy for Destroyed Lung
}

\author{
๑ Illker Kolbaş, @ Çağatay Tezel,2 $\odot$ Serdar Evman, ${ }^{2}$ \\ - Serkan Bayram, ${ }^{2}$ ๑ Volkan Baysungur ${ }^{2}$
}

\footnotetext{
'Department of Thoracic Surgery Sultan Abdülhamid Han Training and

Research Hospital, İstanbul, Turkey

²Department of Thoracic Surgery,

Süreyyapaşa Chest Diseases and Thoracic Surgery Training and Research Hospital, İstanbul, Turkey

Submitted: 10.11.2018 Accepted: 02.01.2019

Correspondence: Illker Kolbaș, İstanbul Sultan Abdülhamid Han Eğitim ve Araştırma Hastanesi, Üsküdar, 34668 İstanbul, Turkey E-mail: dr_ilkerkolbas@hotmail.com

Keywords: Bronchiectasis;
destroyed lung; minimally
invasive surgery; pulmonary
resection.
}

\begin{abstract}
Destroyed lung is a term used when there is disseminated destruction of the lung parenchyma caused by a chronic infectious or inflammatory pulmonary disease. Tuberculosis and bronchiectasis are the most common causes of destroyed lung described in the literature. The main hindrances to use of a videothoracoscopic (VATS) surgical approach in these cases are dense fibrotic adhesions or additional shrinkage of the thoracic cavity as a result of chronic inflammation. A 42-year-old woman presented with the complaint of intervals of hemoptysis, which had been ongoing for 6 months. Thorax computed tomography showed generalized bronchiectasis and parenchymal destruction in the right lung. A right pneumonectomy was performed via the 2-port VATS technique. This case was presented in order to demonstrate that even during a thoracotomy with adhesiolysis and difficult vessel dissection, VATS resection can be performed safely, and to highlight some of the potential intraoperative difficulties.
\end{abstract}

\section{INTRODUCTION}

Destroyed lung is end-stage pulmonary damage, induced by chronic inflammatory or infectious lung diseases. ${ }^{[1]}$ A pneumonectomy for destroyed lung is relatively safe with morbidity and mortality rates in tolerable ranges. ${ }^{[2]}$ Anatomical resection performed using videothoracoscopic surgery (VATS) has proven to be successful in early-stage lung cancer and benign pulmonary diseases over the last 2 decades..$^{[3]}$ This is a description of a VATS pneumonectomy performed for a destroyed lung.

\section{CASE REPORT}

A 42-year-old woman presented with hemoptysis, which had progressed in the last 6 months. Computed tomography of the thorax revealed generalized bronchiectasis and parenchymal destruction in the right lung (Fig. Ia). She had no medical history of tuberculosis, and the sputum microbiological cultures were negative. Ventilation-perfusion scintigraphy showed markedly decreased perfusion (11\%) in the right lung (Fig. Ib).

After receiving a routine consent form, a decision was made to perform a VATS pneumonectomy. Under general anesthesia with left single-lung intubation, the patient was placed in the left lateral decubitus position. Employing a $10-\mathrm{mm}$ trocar, a $30^{\circ}$ thoracoscope was placed through the seventh intercostal space in the mid-axillary line and a 4-cm utility incision was made in the fourth intercostal space in the anterior axillary line. A rib retractor was not used. The adhesions were separated using blunt and sharp dissection. Endo Peanut, Roticulator Endo Shears, Roticulator Endo Grasp (Covidien, plc, Dublin, Ireland), and harmonic cautery were used to perform the dissection.

The lung was freed from the diaphragmatic surface to the inferior pulmonary vein, and anterior dissection continued through the pericardium. In order to reduce possible bleeding before posterior dissection, the inferior pulmonary vein, superior pulmonary vein, and right pulmonary artery were each divided with an endovascular stapler. Dissection continued in front of the vertebrae over the esophagus to find the right cleavage dorsally. Subsequently, in order to maintain proper vascularization at the stump and avoid a possible hemorrhage from the bronchial artery, the right main bronchus was divided with a stapler without extensive peribronchial dissection, and 

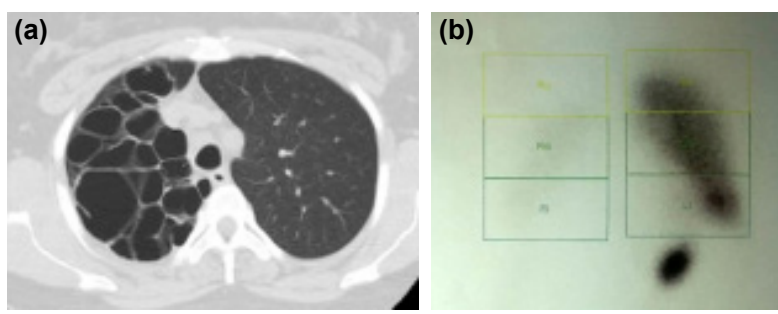

Figure 1. (a) Computed tomography scan revealing destroyed right lung. (b) Ventilation-perfusion scintigraphy scan.
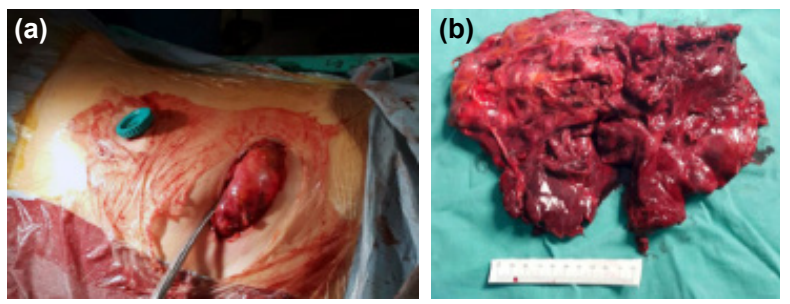

Figure 2. (a) Lung removed via utility incision. (b) Surgical specimen from right pneumonectomy.

the specimen was removed (Fig. 2a and b) using a utility incision. The postoperative course was uneventful. The patient was discharged on the fifth postoperative day and remained asymptomatic at 2 years of follow-up.

\section{DISCUSSION}

Destroyed lung is the term used in literature to describe generalized lung damage after a process of chronic pulmonary aggravation, usually by an infectious disease. ${ }^{[1]}$ In patients with destroyed lung, pulmonary function is greatly decreased. ${ }^{[2]}$ Surgical resection is the last and only curative treatment choice for patients with unilateral total lung perfusion of less than $10 \%$ or $15 \%{ }^{[1]}$ Our patient's right lung perfusion was $11 \%$ and resection was indicated in accordance with the literature.

Surgical intervention techniques to minimize morbidity and mortality and increase patient comfort and quality of life continue to advance. The first VATS lobectomy in the literature was reported by Roviaro et al. ${ }^{[3]}$ in 1991. With recent developments in minimally invasive surgery, great improvements in thoracic surgery have been seen. ${ }^{[4]}$ Numerous VATS lung resections have been performed in the last 2 decades since the first thoracoscopic lobectomy. ${ }^{[5-7]}$

The primary advantages of a VATS lobectomy are less postoperative pain, improved postoperative pulmonary functions, a shorter hospital stay, diminished triggering of the immune system, and a quicker recovery. ${ }^{[4,6,7]}$ However, the majority of lobectomies are still performed via thoracotomy. ${ }^{[4,5]}$ Most studies and meta-analyses regarding VATS lobectomy have examined early-stage lung malignancies. ${ }^{[7]}$ The first series of studies on VATS pneumonectomy for a malignancy was published by Craig et al. ${ }^{[8]}$ in 1995.The method is thought to be feasible for the surgical treatment of benign diseases like bronchiectasis. ${ }^{[3,4-6]}$
The usual course of patients with destroyed lung is generally complicated by recurrent pulmonary infections that lead to the formation of adhesions. ${ }^{[l]}$ Dissection of these dense adhesions during pulmonary resections results in prolonged operative time, excessive blood loss, and increased surgical morbidity ${ }^{[1,7]}$ The most common reason stated in the literature for conversion from a VATS procedure to thoracotomy is the presence of pleural adhesions in the thoracic cavity caused by chronic infections and inflammation. ${ }^{[5,6]}$ In our case, we noticed that dense adherences could be overcome by patient and meticulous dissection. With persistence, the thick fibrotic adhesions were freed using sharp and blunt dissection.

In conclusion, shrinkage of the thoracic cavity and the presence of dense adhesions in patients with chronic pulmonary infectious diseases can cause technical difficulty for a VATS procedure, but should not be seen as a contraindication for this approach. There was no additional difficulty in completing the resection after achieving the separation of the dense adhesions, which are accepted as a relative contraindication for a minimally invasive technique. All thoracic operations, especially those performed for benign diseases, should be carried out via minimally invasive techniques, if possible, without creating any additional risk to the patient.

\section{Informed Consent}

Written informed consent was obtained from the patient for the publication of the case report and the accompanying images.

\section{Peer-review}

Internally peer-reviewed.

Authorship Contributions

Concept: I.K., Ç.T.; Design: S.E., V.B.; Data collection \&/or processing: Ç.T., i.K.; Analysis and/or interpretation: I.K., Ç.T.; Literature search: S.B., S.E.; Writing: I.K., Ç.T.; Critical review: I.K., Ç.T., S.E., S.B., V.B.

Conflict of Interest

None declared.

\section{REFERENCES}

1. Olgac G, Yilmaz MA, Ortakoylu MG, Kutlu CA. Decision making for lung resection in patients with empyema and collapsed lung due to tuberculosis. Thorac Cardiovasc Surg 2005;130:131-5. [CrossRef]

2. Li Y, Hu X, Jiang G, Chen C. Pneumonectomy for treatment of destroyed lung: A retrospective study of 137 patients. Thorac Cardiovasc Surg 2017;65:528-34. [CrossRef]

3. Roviaro G, Varoli F, Rebuffat C, Vergani C, D'Hoore A, Scalamdra SM, et al. Major Pulmonary Resections: Pneumonectomies and Lobectomies. Ann Thorac Surg 1993;56:779-83. [CrossRef]

4. Eren S, Eren MN, Balci AE. Pneumonectomy in children for destroyed lung and the long-term consequences. J Thorac Cardiovasc Surg 2003;126:574-81. [CrossRef]

5. Doğruyol T, Tezel C. New technological instruments in thoracic surgery. Turkiye Klinikleri J Thor Surg Special Topic 2017;8:361-8.

6. Baysungur V, Dogruyol T, Ocakcioglu I, Misirlioglu A, Evman S, Kanbur S, et al. The Feasibility of Thoracoscopic Resection in Bronchiecta- 
sis. Surg Laparosc Endosc Percutan Tech 2017;27:194-6. [CrossRef]

7. Hartwig MG, D'Amico TA. Thoracoscopic lobectomy: The gold standard for early-stage lung cancer. Ann Thorac Surg 2010;89:
2098-101. [CrossRef]

8. Craig SR, Walker WS. Initial experience of video assisted thoracoscopic pneumonectomy. Thorax 1995;50:392-5. [CrossRef]

\section{Harap Akciğerli Olguda Videotorakoskopik Sağ Pnömonektomi}

"Harap akciğer" terimi; kronik enfeksiyöz veya enflamatuvar bir hastalığın neden olduğu, akciğer parankiminin yaygın harabiyeti için kullanılır ve literatürde bildirilen, harap akciğer oluşumuna yol açan en sık nedenler tüberküloz ile bronşektazidir. Kronik enflamasyona bağlı yoğun fibrozis veya toraks kavitesinin küçülmesi, bu olgularda videotorakoskopik yaklaşımın önündeki en önemli problemdir. Kırk iki yaşında kadın hasta altı aydır devam eden hemoptizi şikayeti ile kliniğe başvurdu. Bilgisayarlı toraks tomografisinde sağ akciğerde yaygın bronşektazi ve parankim harabiyeti izlendi. Hastaya iki portlu videotorakoskopik yöntemle sağ pnömonektomi uygulandı. Geleneksel torakotomi uygulanan hastalarda bile yapışıkıkların ayrılması ve damar diseksiyonunun zor olduğu harap akciğer olgusunda, hızla gelişen torakoskopik cerrahi tekniğin güvenli bir şekilde kullanılabileceği göstermeyi amaçladık. Olgumuzu intraoperatif zorluklara değinmek amacıyla sunuyoruz.

Anahtar Sözcükler: Akciğer rezeksiyonu; bronşektazi; harap akciğer; minimal invaziv cerrahi. 